

\section{Sumário}

Editorial: ConstituCiOnalismo latino-AMERICANO: O QUE TEMOS EM COMUM? .15

Editorial: Constitucionalismo Latinoamericano: ¿Qué TENEMOS EN COMÚN? 17 Luís Roberto Barroso e Patrícia Perrone Campos Mello

Seção I: Poder Constituinte

As Constituições latino-AMERICANAS ENTRE A VIDA E A MORTE: POSSIBILIDADES E LIMITES DO PODER DE EMENDA

Luís Roberto Barroso e Aline Osorio

Criação constitucional sem Poder Constituinte: Os limites conceituais do poder de SUBSTITUIÇÃO OU REVISÃO DA CONSTITUIÇÃO

Carlos Bernal Pulido

Quem Conta Como naÇão? A ExClusão de temáticas LGBTI nas asSEMbleias CONSTituintes de Brasil e Colômbia

Rafael Carrano Lelis, Marcos Felipe Lopes de Almeida e Waleska Marcy Rosa

Em Defesa da PaRTicipaÇão: ANálise da iniciativa POPUlar Para alteraÇão da Constituição no Brasil E No EquAdor

Ilana Aló Cardoso Ribeiro e Lílian Márcia Balmant Emerique

Reflexões críticas sobre o Processo Constituinte Equatoriano de Montecristi (2007-2008)

E. Emiliano Maldonado

SeÇão II: Jurisdição Constitucional e Democracia

LA REVISIÓN JUDICIAL EN DEMOCRACIAS DEFECTUOSAS 154 Roberto Gargarella

Constituição E PluRalismo JURÍdico: A POSIÇÃo PARTICUlar do Brasil NO CONTEXTO LATINO-AMERICANO

Ana Paula Gonçalves Pereira de Barcellos

As CONSTITUiÇões LATINO-AMERICANAS PELAS LENTES DAS CORTES CONSTITUCiONAIS: A FORÇA NORMATIVA E O ROMANTISMO DOS PREÂMBULOS 185 Arnaldo Sampaio de Moraes Godoy e Carlos Frederico Santos 
REDES SOCIALES, JUSTICIA CONSTITUCIONAL Y DELIBERACIÓN PÚBLICA DE CALIDAD: LECCIONES DEL Plebiscito por la PAZ EN Colombia...........................................................203 Jorge Ernesto Roa Roa

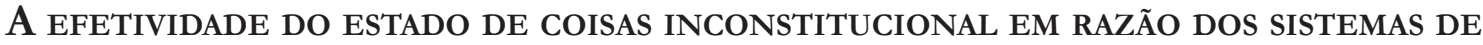
monitoramento: uma aNÁlise comparativa ENTRE Colômbia E Brasil 218

Aléssia Barroso Lima Brito Campos Chevitarese, Ana Borges Coêlho Santos e Felipe Meneses Graça

Seção III: Constitucionalismo Transformador e "Ius Constitucionale Commune" na AmÉRica LATina 231

O MANDATO TRANSFORMADOR DO Sistema INTERAMERICANO: LEgALIDADE E LEGITIMIDADE DE UM PROCESSO JURISGENÉTICO EXTRAORDINÁRIO 233 Armin von Bogdandy

CONSTITUCIONALISMO, TRANSFORMAÇÃO E RESILIÊNCIA DEMOCRÁTICA NO BRASIL: O IUS Constitucionale Commune na América Latina tem uma Contribuição a oferecer? .. 254 Patrícia Perrone Campos Mello

UM PROJETO COMUM PARA A AMÉRICA LATINA E OS IMPACTOS DAS EMPRESAS EM DIREITOS HUMANOS .287

Danielle Anne Pamplona

O papel da Corte Interamericana de Direitos humanos na construção dialogada do Ius Constitutionale Commune na América Latina..............................................303 Ana Carolina Lopes Olsen e Katya Kozicki

Seção IV: Novo Constitucionalismo Latino-Americano

O papel da Corte Interamericana de Direitos humanos na construÇão dialogada do Ius Constitutionale Commune na América Latina.................................................334 Roberto Viciano Pastor e Rubén Martínez Dalmau

¡Que viva El Estado Plurinacional!: ¿Y lo socioambiental? 351 Anibal Alejandro Rojas Hernández, aula Harumi Kanno, Heline Sivini Ferreira e Adriele Fernanda Andrade Précoma

O NOVO CONSTITUCIONALISMO LATINO-AMERICANO: ANÁLISE MARXISTA DA INVISIBILIZAÇÃO DA LUTA DE CLASSES NAS INVESTIGAÇÕES JURÍDICAS CRÍTICAS .365

Daniel Araújo Valença, Ronaldo Moreira Maia Júnior e Rayane Cristina de Andrade Gomes

O NOVO CONSTITUCIONALISMO LATINO-AMERICANO: ANÁLISE MARXISTA DA INVISIBILIZAÇÃO DA LUTA DE CLASSES NAS INVESTIGAÇÕES JURÍDICAS CRÍTICAS .382

Adriele Andrade Précoma, Heline Sivini Ferreira e Rogério Silva Portanova 
O direito À ÁGUA NAs Constituições da América do Sul: Elementos comuns e traços DISTINTIVOS.

Thiago Rafael Burckhart e Milena Petters Melo

Direitos Humanos na América Latina: avanços e desafios inerentes À atual CONJUNTURA POLÍTICA

Paulo Renato Vitória e Gabriela Maia Rebouças

O Novo Constitucionalismo na América latina e Caribe, e a construção do direito À SAÚDE

Alethele de Oliveira Santos, Maria Célia Delduque e Moacyr Rey Filho

A qualidade da educaÇão para a EFETIVaÇão E Consolidação do novo CONSTITUCIONALISMO LATINO-AMERICANO NO EQUADOR E NA BOLÍVIA.

Manuel Rodrigues de Sousa Junior e Luigi Bonizzato

A diversidade Cultural segundo o entendimento da Corte InTERAmericana de Direitos Humanos e o Novo Constitucionalismo Latino-Americano transformador. 476 Bianor Saraiva Nogueira Júnior, Deicy Yurley Parra Flórez e Ulisses Arjan Cruz dos Santos

UN APORTE A LA PROTECCIÓN DE LOS DERECHOS HUMANOS EN LATINOAMÉRICA: LA ACTIVIDAD del Ombudsman Criollo en tribunales de justicia 493 Juan Pablo Díaz Fuenzalida

SEÇÃo VI: Povos Indígenas

El DERECHO FUNDAMENTAL A LA IDENTIDAD CULTURAL DE LOS PUEBLOS INDÍGENAS: UN DERECHO-MATRIZ Y FILTRO HERMENÉUTICO PARA LAS CONSTITUCIONES DE AMÉRICA LATINA: LA JUSTIFICACIÓN 514 Juan Jorge Faundes

Povos INDígenas E A (AUSÊNCIA DE) JUSTIÇA DE TRANSIÇÃo BRASILEIRA: UMA ANÁLISE À LUZ DO CONSTITUCIONALISMO PLURALISTA LATINO-AMERICANO Jamilly Izabela de Brito Silva e Sílvia Maria da Silveira Loureiro

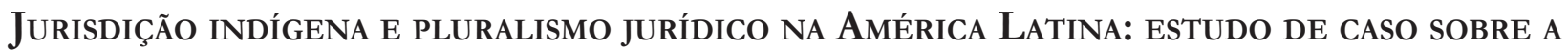
JUSTIÇA WAIWAI .558 João Vitor Cardoso e Luiz Guilherme Arcaro Conci

O NOVO CONSTITUCIONALISMO LATINO-AMERICANO E OS POVOS INDÍGENAS: A VisÃo Do DiREITO A PARTIR dOS CALEIDOSCÓPIOS E DOS MONÓCUlOS 577 Lucas Silva de Souza, Valéria Ribas do Nascimento e Isadora Forgiarini Balem 


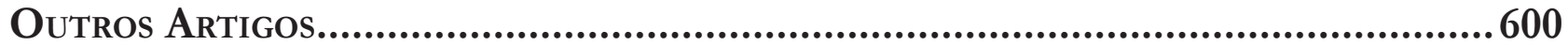

BUILDING TRUST IN COLLABORATIVE PROCESS OF VILLAGE FUND POLICY IMPLEMENTATION (A Case Study at Luwuk District of Banggai Regency) .........................................602 Rahmawati halim 


\title{
Povos indígenas e a (ausência de) justiça de transição brasileira: uma análise à luz do constitucionalismo pluralista latino-americano*
}

\author{
Indigenous peoples and (the abscence of) \\ transitional justice in brazil: an analysis \\ in the light of latin american pluralist \\ constitutionalism
}

Jamilly Izabela de Brito Silva**

Sílvia Maria da Silveira Loureiro***

* Recebido em 27/05/2019

Aprovado em 31/07/2019

** Discente do Programa de Pós-Graduação em Direito Ambiental (PPGDA-UEA). Atua como Assessora Jurídica da Presidência do Tribunal Regional Eleitoral do Amazonas (TRE/ AM), colabora com os trabalhos desenvolvidos pela Clínica de Direitos Humanos e Direito Ambiental (CDHDA-UEA) e participa do Grupo de Pesquisa "Direitos Humanos na Amazônia”. É graduada em Direito pela Universidade do Estado do Amazonas, com Habilitação em Direito Internacional. Possui Pós-Graduação Lato Sensu em Direito Civil e Direito Processual Civil e em Direito Público, ambas pelo Centro Universitário de Ensino Superior do Amazonas (CIESA). E-mail : jamilly. izabela@gmail.com

*** Doutora em Direito (área de concentração em Teoria do Estado e Direito Constitucional) pela Pontifícia Universidade Católica do Rio de Janeiro. Atua como professora do Curso de Direito e do Programa de Pós-Graduação em Direito Ambiental da Escola Superior de Ciências Sociais da Universidade do Estado do Amazonas (ESO/UEA), nas áreas de Direito Constitucional e Direito Internacional. Desenvolve atividades de pesquisa e extensão na Clínica de Direitos Humanos e Direito Ambiental da ESO/UEA. É graduada em Direito pela Universidade Federal do Amazonas (UFAM), possui especialização em Direito Processual pelo Instituto Superior de Administração e Economia da Amazônia/Fundação Getúlio Vargas e Mestrado em Direito e Estado pela Universidade de Brasília (UnB). E-mail : silviamsloureiro@gmail.com.

\section{Resumo}

O artigo objetiva debater se o constitucionalismo pluralista latino-americano pode funcionar como embasamento teórico para que se efetive uma justiça de transição em favor dos povos indígenas que sofreram graves violações de direitos humanos durante o regime de exceção brasileiro (1964-1985). Nesse panorama, num primeiro momento, será esmiuçado o conceito de justiça de transição, bem como brevemente explicitados os posicionamentos contraditórios do Estado brasileiro sobre o tema. Em seguida, a pesquisa apresentará as principais violações de direitos humanos cometidas durante o período de exceção contra os povos indígenas Waimiri-Atroari e Krenak, bem como a ausência, por ora, de mecanismos de transição específicos, voltados à reparação de violações que ameaçaram a própria existência desses povos. Por fim, serão analisadas as aproximações existentes entre o constitucionalismo pluralista latino-americano e a Constituição Federal de 1988, seja para situar o atual marco constitucional brasileiro no âmbito desse movimento constitucional, seja para demonstrar o papel que pode ser desempenhado pelo constitucionalismo pluralista latino-americano como vetor para a mudança do paradigma vigente. $\mathrm{O}$ método de pesquisa utilizado será o indutivo. A pesquisa é, ainda, qualitativa, a partir de estudo de caso e será executada por intermédio da análise crítica do material bibliográfico e documental.

Palavras-chaves: Constitucionalismo pluralista latino-americano, justiça de transição, povos indígenas

\section{Abstract}

The article aims to discuss whether Latin American pluralistic constitutionalism can work as a theoretical basis for transitional justice in favor of indigenous peoples who suffered serious human rights violations during the Brazilian exception regime (1964-1985). In this scenario, will be first examined the concept of transitional justice and then briefly exposed the contradictory positions of the Brazilian State on the subject. The research will then 
present the main human rights violations committed in the exception regime against the indigenous peoples Waimiri-Atroari and Krenak, as well as the absence, for the moment, of specific transition mechanisms, aimed at repairing violations that threatened the very existence of these peoples. Finally, will be analyzed the existing approaches between Latin American pluralist constitutionalism and the Federal Constitution of 1988, either to situate the current Brazilian constitutional framework within this constitutional movement, or to demonstrate the role that can be played by Latin American pluralist constitutionalism as a vector for change of the current paradigm. The research method used is the inductive. The research is also qualitative, based on a case study and will be performed through the critical analysis of selected bibliography and documents.

Keywords: Latin american pluralist constitutionalism. Transitional justice. Indigenous peoples.

\section{Introdução}

No dia 10 de dezembro de 2014, a Comissão Nacional da Verdade (CNV) ${ }^{1}$ apresentou seu Relatório Final $^{2}$, destacando, entre tantas outras, as violações de direitos humanos dos povos indígenas no recente período de exceção brasileiro (1964-1985).

O documento estima que, pelo menos, 8.350 (oito mil trezentos e cinquenta) indígenas morreram em decorrência da ação direta do Estado ou de sua omissão, sendo certo que

[...] os diversos tipos de violações dos direitos humanos cometidos pelo Estado brasileiro [...] se articularam em torno do objetivo central de forçar ou acelerar a 'integração' dos povos indígenas e colonizar seus territórios”,

conforme fosse considerado estratégico para a implementação do então vigente projeto político e econômico.

Na mesma conjuntura fática do regime de exceção brasileiro, entrou em vigor o Estatuto do Índio (Lei n ${ }^{\circ}$ 6.001/73), legislação infraconstitucional que é marcadamente caracterizada como integracionista e, portanto, verdadeiro corolário da suposta necessidade de "tutelar" os povos originários até sua completa absorção pela sociedade envolvente.

É certo, todavia, que a Constituição Federal de 1988 inaugurou, para o Estado brasileiro, o respeito à di-

1 Criada pela Lei no $12.528 / 2011$ e instituída em 16.05.2012. O período investigado abrange os anos de 1946 a 1988 e, portanto, os anos do regime de exceção brasileiro (1964-1985).

2 O material é bastante extenso e se encontra assim dividido: (1) Volume I (Parte I - A Comissão Nacional da Verdade; Capítulo 1 - A criação da Comissão Nacional da Verdade; Capítulo 2 - As atividades da CNV; Parte II - As estruturas do Estado e as graves violações de direitos humanos; Capítulo 3 - Contexto histórico das graves violações entre 1946 e 1988; Capítulo 4 - Órgãos e procedimentos da repressão política; Capítulo 5 - A participação do Estado brasileiro em graves violações no exterior; Capítulo 6 - Conexões internacionais: a aliança repressiva no Cone Sul e a Operação Condor; Parte III - Métodos e práticas nas graves violações de direitos humanos e suas vítimas; Capítulo 7 - Quadro conceitual das graves violações; Capítulo 8 - Detenções ilegais e arbitrárias; Capítulo 9 - Tortura; Capítulo 10 - Violência sexual, violência de gênero e violência contra crianças e adolescentes; Capítulo 11 - Execuções e mortes decorrentes de tortura; Capítulo 12 - Desaparecimentos forçados; Parte IV - Dinâmica das graves violações de direitos humanos: casos emblemáticos, locais e autores O Judiciário; Capítulo 13 - Casos emblemáticos; Capítulo 14 - A Guerrilha do Araguaia; Capítulo 15 - Instituições e locais associados a graves violações de direitos humanos; Capítulo 16 - A autoria das graves violações de direitos humanos; Capítulo 17 - O Judiciário na ditadura; Parte V - Conclusões e recomendações; Capítulo 18 - Conclusões e recomendações); (2) Volume II - Textos Temáticos (Texto 1 - Violações de direitos humanos no meio militar; Texto 2 - Violações de direitos humanos dos trabalhadores; Texto 3 - Violações de direitos humanos dos camponeses; Texto 4 - Violações de direitos humanos nas igrejas cristãs; Texto 5 - Violações de direitos humanos dos povos indígenas; Texto 6 - Violações de direitos humanos na universidade; Texto 7 - Ditadura e homossexualidades; Texto 8 - Civis que colaboraram com a ditadura e; Texto 9 - A resistência da sociedade civil às graves violações de direitos humanos) e; (3) Volume III - Mortos e Desaparecidos Politicos (Índice em ordem alfabética; Índice em ordem cronológica; Introdução; 1950 - 1969; 1970 - 1971; 1972 - maio de 1973; Junho de 1973 - abril de 1974 e Maio de 1974 - outubro de 1985). A íntegra do documento encontra-se disponível em: http:/ / cnv.memoriasreveladas.gov.br/. Acesso em: 10 maio 2019.

3 BRASIL. Comissão Nacional da Verdade. Relatório final. Brasília: CNV, 2014. (v. 2, texto 5). p. 251. Disponível em: http://cnv. memoriasreveladas.gov.br/. Acesso em: 10 maio 2019. 
versidade cultural dos povos indígenas ao assegurar, em seu art. 231, o reconhecimento de "sua organização social, costumes, línguas, crenças e tradições, e os direitos originários sobre as terras que tradicionalmente ocupam".

Nesse panorama, o texto constitucional brasileiro atual, em certos aspectos, pode ser inserido no contexto do constitucionalismo pluralista latino-americano, para utilizar a nomenclatura de Raquel Yrigoyen Fajardo ${ }^{4}$ Em suma, o horizonte pluralista busca suplantar os modelos constitucionais liberal e social que, entre outras coisas, visam tutelar e integrar os povos indígenas à sociedade envolvente, para reconhecer a igual dignidade das culturas, rompendo com a supremacia institucional da cultura ocidental sobre as demais e trazendo consigo o direito à identidade cultural, individual e coletiva, e o caráter de sujeito coletivo dos povos e comunidades indígenas e demais comunidades tradicionais, inclusive afrodescendentes e campesinas.

Com essas considerações, a (ausência de) "transição" do regime de exceção para a democracia brasileira e da legislação integracionista para a legislação pluralista, especificamente em relação aos povos indígenas, é o ponto de partida do presente artigo que pretende responder a seguinte indagação: o constitucionalismo pluralista pode funcionar como embasamento teórico para que se efetive uma justiça de transição em favor dos povos indígenas que sofreram graves violações de direitos humanos durante o regime de exceção brasileiro (1964-1985)?

Para tanto, na primeira seção, o estudo se dedicará a esmiuçar o conceito de justiça de transição, bem como explicitar, ainda que de forma breve, como o Estado brasileiro possui posicionamentos contraditórios sobre o tema, ora reconhecendo a ocorrência de graves violações de direitos humanos para fins meramente civis e/ou indenizatórios, ora se utilizando da Lei de Anistia (Lei no 6.683/79) para impedir a investigação e punição criminal dos responsáveis pelas atrocidades cometidas durante o regime de exceção.

Ato contínuo, na segunda seção, a pesquisa apresentará, com base no Relatório emitido pela Comissão Nacional da Verdade (CNV), as principais violações de direitos humanos cometidas contra os povos indígenas Waimiri-Atroari e Krenak ${ }^{5}$, bem como a inexistência, por ora, de mecanismos de transição específicos, voltados à reparação de violações que ameaçaram a própria existência desses povos.

\footnotetext{
4 O presente artigo utilizará como diretriz o constitucionalismo pluralista de Raquel Yriggen Fajardo. Por oportuno, convém ressaltar que o constitucionalismo pluralista se encontra inserido no que se convencionou denominar Novo Constitucionalismo Latino-Americano (NCLA). Em suma, o NCLA é uma teoria constitucional surgida na América Latina em que diversos autores, com algumas diferenças entre si, refletem sobre as reivindicações de diversos movimentos sociais, inclusive movimentos indígenas, de comunidades tradicionais e de afrodescendentes — com algumas diferenças entre si - combinadas com propostas políticas adotadas pelo povo num cenário de elevado conflito social e político. Nesse sentido, sintetiza Rubén Martínez Dalmau, em tradução livre: "No âmbito do constitucionalismo, o poder constitucional e o poder constituído adquirem significado um no outro. O poder constituído obtém sua legitimidade do constituinte, e este é consciente de que sua efervescência é uma faculdade extraordinária que acabará por separar seus componentes e destilar o produto legitimado e legitimador chamado Constituição. É precisamente essa consciência em relação ao potencial revolucionário do poder constituinte, que finca suas raízes na origem do conceito, mas que, ao mesmo tempo, tem sido conscientemente ignorada pelos constituintes das elites, o que diferencia o velho e o novo constitucionalismo na América Latina. Desse ponto de vista, o novo constitucionalismo latino-americano é um constitucionalismo sem país. Ninguém, tirando o povo, pode se sentir o pai da Constituição, considerando a genuína dinâmica participativa e legitimadora que acompanha os processos constituintes. Desde a própria ativação do poder constituinte por meio de um referendo, até a votação final para sua entrada em vigor [...], passando pela introdução participativa de seus conteúdos, os processos estão cada vez mais se afastando daqueles encontros de elites do antigo constitucionalismo para entrar, com suas vantagens e desvantagens, em seu próprio caos, a partir do qual se obterá um novo tipo de Constituição: mais abrangente e detalhada, de maior originalidade, pensada para servir ao povo” (p. 6). Cfr. DALMAU, Rubén Martínez. Asambleas constituíntes e novo constitucionalismo en América Latina. Tempo Exterior, n. 17, p. 5-15, 2008, ISSN 1579-6582. Disponível em: https://dialnet.unirioja.es/servlet/articulo?codigo=5862528. Acesso em: 20 mar. 2019.

5 Convém esclarecer que somente serão mencionadas as violações cometidas contra os povos indígenas Waimiri-Atroari e Krenak por razões exclusivamente metodológicas, tendo em conta, inclusive, as delimitações inerentes ao escopo do estudo que ora se apresenta. De fato, o Texto 5 do Volume II do Relatório da CNV, lamentavelmente, relata uma infinidade de violações cometidas contra os povos indígenas, relacionadas aos mais variados assuntos, a saber: política fundiária e esbulho de terras indígenas; usurpação de trabalho indígena, confinamento e abusos de poder; contatos e às remoções forçadas; omissão nas políticas públicas de saúde; certidões negativas fraudulentas de existência de índios; expulsão, remoção e intrusão de territórios indígenas; desagregação social e extermínio; mortandades e massacres; invasões, garimpo, desassistência e morte; prisões, torturas, maus-tratos e desaparecimentos forçados e; perseguições ao movimento indígena.
} 
Por fim, na última seção, serão analisadas as aproximações existentes entre o constitucionalismo pluralista e a Constituição Federal de 1988, seja para situar o atual marco constitucional brasileiro no âmbito desse movimento constitucional desenvolvido na América Latina, seja para, em última análise, demonstrar o papel que pode ser desempenhado pelo constitucionalismo pluralista como vetor para a mudança do paradigma vigente.

O método de pesquisa utilizado será o indutivo. O procedimento de pesquisa adotado será a pesquisa qualitativa, especificamente o estudo de caso $^{6}$, sendo certo que o estudo será executado por intermédio da busca, seleção, leitura e análise crítica do material bibliográfico e documental disponível em livros, documentos oficiais, processos judiciais, artigos em periódicos especializados e publicações acadêmicas.

\section{Justiça de transição: diferentes formas de enfrentar o passado}

A justiça de transição ${ }^{7}$ "é um campo multidisciplinar de pesquisa e prática ligado à luta contra a impunidade e aos domínios mais amplos dos direitos humanos e da resolução de conflitos" ${ }^{\text {. }}$. Em outras palavras, a expressão em questão refere-se a diversas políticas estatais de enfrentamento das graves violações aos direitos humanos (legados de abuso em massa - legacies of mass abuse) perpetradas em períodos autoritários, não democráticos e/ou de guerra.

Para tal desiderato, são utilizados diversos mecanismos, entre os quais podem ser citados meios formais e informais não judiciais e quase-judiciais, como comissões da verdade, programas de reparação de vítimas e medidas de reforma institucional, especialmente do aparato de segurança pública; a revelação da verdade e a promoção da memória e; a responsabilização, inclusive criminal, dos perpetradores das graves violações, tudo com o objetivo de consolidar a democracia, acelerar a reconciliação e garantir a não-repetição.

Em suma, a justiça de transição, por regra, encontra-se caracterizada quando são utilizados mecanismos não judiciais e quase judiciais devidamente acompanhados por julgamentos (persecução penal).

Assim, ainda que cada processo transicional seja diferente e as medidas que serão adotadas possam ser diversas, é possível identificar 04 (quatro) obrigações a serem cumpridas por parte dos Estados na justiça de transição, a saber: (a) conhecer a verdade dos fatos; (b) democratizar a política (qualidade das reformas); (c) reparar as vítimas e seus familiares e; (d) proporcionar a responsabilização dos autores? ${ }^{9}$.

É indubitável, portanto, que, no processo de transição, os direitos à justiça, à verdade e à memória devem ser assegurados, seja para garantir o acesso público às informações, seja para exigir que o Estado adote medidas que assegurem entender o que ocorreu, por que ocorreu e quem são os responsáveis, ainda que seja necessário buscar uma aplicação da justiça restaurativa, para além da justiça meramente punitiva, como forma de conciliá-la com os ideais de paz e reconciliação.

Ora, o ideal de justiça ligado à justiça de transição deve ser entendido de forma ampla, "indo mais além

\footnotetext{
Sobre o método de pesquisa e o procedimento de pesquisa utilizados no presente artigo, cfr. MEZZAROBA, Orides; MONTEIRO, Cláudia Servilha. Manual de metodologia da pesquisa no direito. 7. ed. São Paulo: Saraiva, 2017. p. 90-93, 138-140 e 149-151.

7 O conceito de justiça de transição é recente. De fato, aponta-se que, em 1992, foi a primeira vez que a expressão foi citada. Embora suas raízes históricas remontem a Nuremberg e a antes, o termo justiça de transição não entrou no léxico político moderno até pouco depois da guerra fria. Cfr. AMBOS, Kai et al. Anistia, justiça e impunidade: reflexões sobre justiça de transição no Brasil. Belo Horizonte: Fórum, 2010. p. 9 e FREEMAN, Mark. Necessary evils: amenesties and the search for justice. Nova Iorque: Cambridge Press University, 2009. p. 18 e 255.

8 FREEMAN, Mark. Necessary evils: amenesties and the search for justice. Nova Iorque: Cambridge Press University, 2009. p. 18. As citações diretas dessa obra são traduções livres do texto original em inglês.

9 Cfr., nesse sentido: GARFUNKEL, Ianiv. Verdad y justicia: terminos incompatibles en la justicia transicional. American University International Law Review, v. 32, Iss. 2, Article 7, 2015. Disponível em: https://digitalcommons.wcl.american.edu/auilr/vol32/iss2/7/. Acesso em: 28 mar. 2019. p. 409-410.; AMBOS, Kai et al. Anistia, justiça e impunidade: reflexões sobre justiça de transição no Brasil. Belo Horizonte: Fórum, 2010. p. 158.
} 
da mera justiça penal e incluindo certos elementos-chave tais como responsabilidade, equidade (fairness) na proteção e reivindicação de direitos e na prevenção e punição dos infratores". Dito de outro modo, a justiça de transição busca

[...] muito mais que justiça penal retributiva [...] e abarca a justiça restaurativa [...] na medida em que visa restaurar ou inclusive reconstruir a comunidade (no sentido de justiça 'criativa') ${ }^{10}$.

Feitas tais considerações prefaciais, tem-se que, no caso brasileiro, a linha adotada pela justiça de transição é "permeada por uma descontinuidade lógica" 11 , seja porque as ações adotadas pelo Estado, além de seguirem caminhos alternativos à via punitiva, não foram embasadas na justiça restaurativa, seja porque as medidas para confrontar o passado foram deslocadas para um plano inferior.

De fato, em primeiro lugar, foi editada uma Lei de Anistia (Lei no 6.683/1979), embasada no "mito da existência de um amplo acordo político-social, o qual teria sido bem incorporado pelo perdão concedido a todos os agentes envolvidos"12.

É importante que se diga, todavia, que a anistia foi negociada no âmbito do próprio regime de exceção e, a princípio, não beneficiava os opositores políticos ${ }^{13}$ (somente incluídos no rol de anistiados pela Emenda Constitucional 26/1985 ${ }^{14}$, que convocou a assembleia nacional constituinte da Constituição Federal de 1988), sendo certo, ainda, que a interpretação dada à anistia englobou os crimes políticos e os crimes conexos aos crimes políticos, inclusive as torturas, os desaparecimentos forçados, as execuções extrajudiciais e outras graves violações de direitos humanos.

Somente em meados da década de 90, foi editada a primeira lei que, de alguma forma e no âmbito cível, buscava reparar as violações ocorridas no período de exceção. A Lei n 9.140/95, com as alterações das Leis $\mathrm{n}^{\text {os }} 10.536 / 02$ e 10.875/04, reconheceu como mortas as pessoas desaparecidas em razão de participação, ou acusação de participação, em atividades políticas, no período de 02.09.1961 a 05.10.1988 ${ }^{15}$, e que, por esse motivo, tenham sido detidas por agentes públicos.

Além disso, a referida lei (art. $4^{\circ}$.) criou a Comissão Especial sobre Mortos e Desaparecidos Políticos ${ }^{16}$, cujos objetivos principais eram três: (a) proceder ao reconhecimento das pessoas desaparecidas ou falecidas por causas não naturais em dependências policiais ou em virtude da repressão policial sofrida em manifestações públicas ou em conflitos armados com agentes do poder público; (b) envidar esforços para a localização dos corpos de pessoas desaparecidas no caso de existência de indícios quanto ao local em que possam estar depositados e; (c) emitir parecer sobre os requerimentos relativos a indenização que venham a ser formulados.

A mesma lei, todavia, previu expressamente (art. $2^{\circ}$.) que a aplicação de suas disposições e todos os seus

10 AMBOS, Kai et al. Anistia, justiça e impunidade: reflexões sobre justiça de transição no Brasil. Belo Horizonte: Fórum, 2010. p. 24 e 29.

11 AMBOS, Kai et al. Anistia, justiça e impunidade: reflexões sobre justiça de transição no Brasil. Belo Horizonte: Fórum, 2010. p. 158-192.

12 AMBOS, Kai et al. Anistia, justiça e impunidade: reflexões sobre justiça de transição no Brasil. Belo Horizonte: Fórum, 2010. p. 158-159.

$13 \mathrm{O} \$ 2^{\circ}$. do art. $1^{\circ}$. da Lei de Anistia excetuou expressamente dos benefícios da anistia os delitos comumente cometidos pela oposição armada. Confira-se, in litteris: " $\$ 2^{\circ}$ - Excetuam-se dos benefícios da anistia os que foram condenados pela prática de crimes de terrorismo, assalto, sequestro e atentado pessoal".

14 Cfr. art. $4^{\circ}$., especialmente o $\$ 1^{\circ}$. (" $\$ 1^{\circ}$ É concedida, igualmente, anistia aos autores de crimes políticos ou conexos, e aos dirigentes e representantes de organizações sindicais e estudantis, bem como aos servidores civis ou empregados que hajam sido demitidos ou dispensados por motivação exclusivamente política, com base em outros diplomas legais").

15 Art. $1^{\circ}$. São reconhecidos como mortas, para todos os efeitos legais, as pessoas que tenham participado, ou tenham sido acusadas de participação, em atividades políticas, no período de 2 de setembro de 1961 a 5 de outubro de 1988, e que, por esse motivo, tenham sido detidas por agentes públicos, achando-se, desde então, desaparecidas, sem que delas haja notícias (Redação dada pela Lei no 10.536, de 2002).

16 Ainda no âmbito dessa Comissão, foram editadas as obras intituladas "Direito à Memória e à Verdade" e "Luta, substantivo feminino". A íntegra das obras encontra-se disponível na rede mundial de computadores. 
efeitos deveriam ser orientados "pelo princípio de reconciliação e de pacificação nacional, expresso na Lei n 6.683, de 28 de agosto de 1979 - Lei de Anistia".

Já em 2001, por meio da Medida Provisória no 2.151-317, foi criada a Comissão de Anistia que, apesar do nome, tem por objetivo tão somente examinar e julgar, no âmbito administrativo, os pedidos de indenização formulados por aqueles que foram impedidos de exercer atividades econômicas, em razão de perseguição política, no período compreendido entre 18.09.1946 e 05.10.1988 e, por isso, são declarados anistiados políticos.

No âmbito da mesma Comissão de Anistia, foi desenvolvido um projeto de educação em direitos humanos, intitulado "Caravana da Anistia", o qual "tem por objetivo a realização pública dos julgamentos dos pedidos de indenização, especialmente em escolas, universidades"18.

Finalmente, no ano de 2011, a Lei no 12.528 cria a Comissão Nacional da Verdade (CNV) com a finalidade de

[...] examinar e esclarecer as graves violações de direitos humanos praticadas no período fixado no art. $8^{\circ}$. do Ato das Disposições Constitucionais Transitórias [18 de setembro de 1946 até a data da promulgação da Constituição de 1988], a fim de efetivar o direito à memória e à verdade histórica e promover a reconciliação nacional.

São listados como objetivos da CNV, in litteris:

Art. $3^{\circ}$. São objetivos da Comissão Nacional da Verdade:

I - esclarecer os fatos e as circunstâncias dos casos de graves violações de direitos humanos mencionados no caput do art. 1o;

II - promover o esclarecimento circunstanciado dos casos de torturas, mortes, desaparecimentos forçados, ocultação de cadáveres e sua autoria, ainda que ocorridos no exterior;

III - identificar e tornar públicos as estruturas, os locais, as instituições e as circunstâncias relacionados à prática de violações de direitos humanos mencionadas no caput do art. 1o e suas eventuais ramificações nos diversos aparelhos estatais e na sociedade;

IV - encaminhar aos órgãos públicos competentes toda e qualquer informação obtida que possa auxiliar na localização e identificação de corpos e restos mortais de desaparecidos políticos, nos termos do art. 1o da Lei no 9.140, de 4 de dezembro de 1995;

V - colaborar com todas as instâncias do poder público para apuração de violação de direitos humanos;

VI - recomendar a adoção de medidas e políticas públicas para prevenir violação de direitos humanos, assegurar sua não repetição e promover a efetiva reconciliação nacional; e

VII - promover, com base nos informes obtidos, a reconstrução da história dos casos de graves violações de direitos humanos, bem como colaborar para que seja prestada assistência às vítimas de tais violações.

O trabalho desenvolvido pela CNV foi consolidado em um Relatório apresentado à sociedade brasileira em 10 de dezembro de 2014, composto por três volumes. Nesse ponto, importa consignar que o mandato da CNV não possuía como função punir nem indiciar, criminalmente, qualquer indivíduo violador de direitos humanos, mas antes buscava efetivar os direitos à memória e à verdade e, ainda, fazer "recomendações" ao Estado brasileiro.

Foi por ocasião dos trabalhos da CNV que o Estado brasileiro assumiu, de forma oficial, os crimes cometidos por seus agentes durante o período de exceção, tendo sido confirmado que, pelo menos, 434 mortes e desaparecimentos ocorreram durante o regime de exceção brasileiro (esse número não inclui a morte de indígenas):

17 Ver, ainda, Medida Provisória no 65/2002 posteriormente convertida na Lei no 10.559/2002.

18 AMBOS, Kai et al. Anistia, justiça e impunidade: reflexões sobre justiça de transição no Brasil. Belo Horizonte: Fórum, 2010. p. 163. 
4. A CNV pôde documentar a ocorrência de graves violações de direitos humanos entre 1946 e 1988 , período assinalado para sua investigação, notadamente durante a ditadura militar, que se estendeu de 1964 a 1985. Essa comprovação decorreu da apuração dos fatos que se encontram detalhadamente descritos neste Relatório, nos quais está perfeitamente configurada a prática sistemática de detenções ilegais e arbitrárias e de tortura, assim como o cometimento de execuções, desaparecimentos forçados e ocultação de cadáveres por agentes do Estado brasileiro. Para essa apuração, a CNV valeu-se de elementos consistentes, frutos de sua atividade de pesquisa, bem como de evidências obtidas por órgãos públicos, entidades da sociedade civil e vítimas e seus familiares, que, antes da existência da comissão, se dedicaram a essa busca.

5. No âmbito desse quadro de graves violações de direitos humanos, a CNV teve condições de confirmar 434 mortes e desaparecimentos de vítimas do regime militar, que se encontram identificados de forma individualizada no Volume III deste Relatório, sendo 191 os mortos, 210 os desaparecidos e 33 os desaparecidos cujos corpos tiveram seu paradeiro posteriormente localizado, um deles no curso do trabalho da CNV. Esses números certamente não correspondem ao total de mortos e desaparecidos, mas apenas ao de casos cuja comprovação foi possível em função do trabalho realizado, apesar dos obstáculos encontrados na investigação, em especial a falta de acesso à documentação produzida pelas Forças Armadas, oficialmente dada como destruída ${ }^{19}$.

O Relatório Final da CNV apontou, ainda, a "comprovação do caráter generalizado e sistemático das graves violações de direitos humanos", a "caracterização da ocorrência de crimes contra a humanidade" e a "persistência do quadro de graves violações de direitos humanos", sendo que uma de suas recomendações determinava que os órgãos competentes investigassem a "responsabilidade jurídica — criminal, civil e administrativa — dos agentes públicos que deram causa às graves violações de direitos humanos ocorridas no período investigado", afastando-se, nesses casos,

[...] a aplicação dos dispositivos concessivos de anistia inscritos nos artigos da Lei 6.683, de 28 de agosto de 1979, e em outras disposições constitucionais e legais ${ }^{20}$.

Entretanto, ainda que tenham ocorrido avanços no processo transicional brasileiro, especialmente na seara cível com a fixação de indenizações, o caminho até a conclusão desse processo parece estar longe do fim. De fato, a maior parte das recomendações emanadas da Comissão Nacional da Verdade — as quais envolvem medidas institucionais, reformas constitucionais e legais e medidas de seguimento das ações e recomendações ${ }^{21}$ - — não foram cumpridas, inserindo-se nesse rol a determinação de persecução penal dos

19 BRASIL. Comissão Nacional da Verdade. Relatório final. Brasília: CNV, 2014. v. 1, parte 5. p. 962-963. Disponível em: http:/ /cnv. memoriasreveladas.gov.br/. Acesso em: 10 maio 2019.

20 BRASIL. Comissão Nacional da Verdade. Relatório final. Brasília: CNV, 2014. v. 1, parte 5. p. 965. Disponível em: http://cnv. memoriasreveladas.gov.br/. Acesso em: 10 maio 2019.

21 Seguem as recomendações: (A) medidas institucionais: (1) reconhecimento, pelas Forças Armadas, de sua responsabilidade institucional pela ocorrência de graves violações de direitos humanos durante a ditadura militar (1964 a 1985), (2) determinação, pelos órgãos competentes, da responsabilidade jurídica — criminal, civil e administrativa — dos agentes públicos que deram causa às graves violações de direitos humanos ocorridas no período investigado pela CNV, afastando-se, em relação a esses agentes, a aplicação dos dispositivos concessivos de anistia inscritos nos artigos da Lei no 6.683, de 28 de agosto de 1979, e em outras disposições constitucionais e legais, (3) proposição, pela administração pública, de medidas administrativas e judiciais de regresso contra agentes públicos autores de atos que geraram a condenação do Estado em decorrência da prática de graves violações de direitos humanos, (4) proibição da realização de eventos oficiais em comemoração ao golpe militar de 1964, (5) reformulação dos concursos de ingresso e dos processos de avaliação contínua nas Forças Armadas e na área de segurança pública, de modo a valorizar o conhecimento sobre os preceitos inerentes à democracia e aos direitos humanos, (6) modificação do conteúdo curricular das academias militares e policiais, para promoção da democracia e dos direitos humanos, (7) retificação da anotação da causa de morte no assento de óbito de pessoas mortas em decorrência de graves violações de direitos humanos, (8) retificação de informações na Rede de Integração Nacional de Informações de Segurança Pública, Justiça e Fiscalização (Rede Infoseg) e, de forma geral, nos registros públicos, (9) criação de mecanismos de prevenção e combate à tortura, (10) desvinculação dos institutos médicos legais, bem como dos órgãos de perícia criminal, das secretarias de segurança pública e das polícias civis, (11) fortalecimento das Defensorias Públicas, (12) dignificação do sistema prisional e do tratamento dado ao preso, (13) instituição legal de ouvidorias externas no sistema penitenciário e nos órgãos a ele relacionados, (14) fortalecimento de Conselhos da Comunidade para acompanhamento dos estabelecimentos penais, (15) garantia de atendimento médico e psicossocial permanente às vítimas de graves violações de direitos humanos, (16) promoção dos valores democráticos e dos direitos humanos na educação, (17) apoio à instituição e ao funcionamento de órgão de proteção e promoção dos direitos humanos; (B) reformas constitucionais e legais: (18) revogação da Lei de Segurança Nacional, (19) aperfeiçoamento da legislação brasileira para tipificação das figuras penais correspondentes aos crimes contra a humanidade e ao crime de desapare- 
agentes públicos que deram causa às graves violações de direitos humanos ocorridas no período.

A evidenciar o que ora se afirma, antes mesmo da criação da CNV, podem ser citados os julgamentos da Arguição de Descumprimento de Preceito Fundamental no 153, proferidos pelo Pretório Excelso em abril de 2010, e do caso Gomes Lund e outros c. Brasil (Guerrilha do Araguaia), decidido pela Corte Interamericana de Direitos Humanos em novembro do mesmo ano, por terem desfechos diametralmente opostos - o primeiro reconheceu a validade da Lei de Anistia brasileira e o segundo declarou sua invalidade e incompatibilidade com a Convenção Americana de Direitos Humanos —, trazem implicações político-jurídicas sem precedentes para o Brasil que, até o momento, não emitiu posicionamento definitivo sobre a questão.

Mais recentemente, em novel sentença proferida em 15 de março de 2018, ao julgar o caso Vladimir Herzog c. Brasil, a Corte Interamericana de Direitos Humanos reiterou que, no Sistema Interamericano de Proteção aos Direitos Humanos, do qual o Brasil faz parte por decisão soberana,

são reiterados os pronunciamentos sobre a incompatibilidade das leis de anistia com as obrigações convencionais dos Estados, quando se trata de graves violações de direitos humanos. ${ }^{22}$

Ainda assim, no âmbito interno, o impasse acerca da validade (ou não) da Lei de Anistia permanece, mesmo após a divulgação do já citado Relatório da CNV.

Com relação às violações perpetradas contra os povos indígenas, a situação é ainda mais alarmante. Segundo o próprio Relatório da CNV, ainda não existe - sequer — um número definitivo dos indígenas afetados pelo período de exceção ${ }^{23}$, sendo certo que

[...] o número real de indígenas mortos no período deve ser exponencialmente maior, uma vez que apenas uma parcela muito restrita dos povos indígenas afetados foi analisada e que há casos em que a quantidade de mortos é alta o bastante para desencorajar estimativas. ${ }^{24}$

Mais que isso: ressalvado o Texto 5 do Volume II do Relatório Final da CNV, que será objeto da seção seguinte do presente estudo, as violações de direitos humanos cometidas contra os povos indígenas não são mencionadas no processo transicional brasileiro. Tal fato, por si só, demonstra que os povos indígenas, como se inexistentes fossem, foram desconsiderados pelas poucas, tardias e incompletas tentativas do Estado brasileiro de enfrentar seu passado recente.

cimento forçado, (20) desmilitarização das polícias militares estaduais, (21) extinção da Justiça Militar estadual, (22) exclusão de civis da jurisdição da Justiça Militar federal, (23) supressão, na legislação, de referências discriminatórias das homossexualidades, (24) alteração da legislação processual penal para eliminação da figura do auto de resistência à prisão, (25) introdução da audiência de custódia, para prevenção da prática da tortura e de prisão ilegal; $(C)$ medidas de seguimento das ações e recomendações: (26) estabelecimento de órgão permanente com atribuição de dar seguimento às ações e recomendações da CNV, (27) prosseguimento das atividades voltadas à localização, identificação e entrega aos familiares ou pessoas legitimadas, para sepultamento digno, dos restos mortais dos desaparecidos políticos, (28) preservação da memória das graves violações de direitos humanos e, (29) prosseguimento e fortalecimento da política de localização e abertura dos arquivos da ditadura militar. Cfr.: BRASIL. Comissão Nacional da Verdade. Relatório final. Brasília: CNV, 2014. v. 1, parte 5). p. 964-975. Disponível em: http://cnv.memoriasreveladas.gov.br/. Acesso em: 10 maio 2019. 22 Corte IDH. Caso Herzog e outros vs. BRASIL. Exceções Preliminares, Mérito, Reparações e Custas. Sentença de 15 de março de 2018. Série C, n. 353, parágrafo 279. As citações diretas dessa sentença são traduções livres do texto original em espanhol.

23 Como já mencionado alhures, o número inicial indicado no Relatório da CNV aponta que, pelo menos, 8.350 indígenas morreram durante o regime de exceção (cerca de 1.180 Tapayuna, 118 Parakanã, 72 Araweté, mais de 14 Arara, 176 Panará, 2.650 Waimiri-Atroari, 3.500 Cinta-Larga, 192 Xetá, no mínimo 354 Yanomami e 85 Xavante de Marãiwatsédé). Cr. BRASIL. Comissão Nacional da Verdade. Relatório final. Brasília: CNV, 2014. v. 2, texto 5. p. 254. Disponível em: http://cnv.memoriasreveladas.gov.br/. Acesso em: 10 maio 2019.

24 BRASIL. Comissão Nacional da Verdade. Relatório final. Brasília: CNV, 2014. v. 2, texto 5. p. 205. Disponível em: http://cnv. memoriasreveladas.gov.br/. Acesso em: 10 maio 2019. 


\section{Regime de exceção brasileiro (1964-1985) e povos indígenas: a caracterização da invisibilidade desses povos originários}

Os povos indígenas do Brasil sofrem "violência decorrente de políticas de assimilação, negação de direito às terras e impactos decorrentes do desenvolvimento em larga escala" ${ }^{25}$ desde o chamado "encontro" 26 entre civilizações, ocorrido no âmbito da expansão colonialista promovida especialmente pelas Coroas Portuguesa e Espanhola, no Século XVI, com o apoio do pensamento dominante ${ }^{27}$ e da Igreja Católica que propagava a necessidade de "espalhar a fé cristã".

É certo, ademais, que as violações de direitos humanos dos povos indígenas ocorridas durante o período de exceção, e até mesmo antes do início do regime ${ }^{28}$, como regra, permanecem invisíveis ${ }^{29} 3031$, como se inexistentes fossem para o Estado brasileiro. Exemplifica tal panorama a política estatal integracionista materializada pelo Serviço de Proteção aos Índios e Localização dos Trabalhadores Nacionais (SPILTN), criado em 1910, e substituído pela Fundação Nacional do Índio (FUNAI), a partir de $1967^{32}$ e até o marco constitucional de 1988, cujos efeitos ainda repercutem nos dias atuais.

Durante o regime de exceção (1964-1985), portanto, o status quo ante em relação aos povos indígenas foi mantido e fortalecido pelo Estado brasileiro. Dito isto, para os fins do presente estudo, utilizando os principais casos catalogados no Relatório Final emitido pela CNV como parâmetro, serão a seguir brevemente explicitados apenas dois eixos (ou grupos) principais de violações praticadas pela política estatal contra os

25 SANTOS FILHO, Roberto Lemos dos. Direitos humanos dos povos indígenas. In: FERRAZ, Carolina Valença; LEITE, Glauber Salomão. (coord.). Direito à diversidade. São Paulo: Atlas, 2015. P. 379.

26 O termo é parte da expressão "encontro entre dois mundos" utilizado por Joseph Höffner para designar o momento em que os europeus aportaram na América e tiveram seu primeiro contato com os índios. Cfr.: HÖFFNER, Joseph. La ética colonial española del siglo de oro, cristianismo y dignidad humana. Rivadeneyra: Madrid, 1957. p. 97 e ss.

27 Nesse ponto, importa ressalvar o trabalho desenvolvido pelos pensadores da Escola Ibérica da Paz (séculos XVI e XVII) que, de forma contramajoritária e baseados na recta ratio, questionavam o "direito" das potências marítimas de subjugar os povos indígenas da América. Cfr.: LOUREIRO, Sílvia Maria da Silveira. A reconstrução da subjetividade coletiva dos povos indigenas no direito internacional dos direitos humanos: o resgate do pensamento da escola ibérica da paz (séculos XVI e XVII) em prol de um novo jus gentium para o século XXI. 2015. Tese (Doutorado) - Pontifícia Universidade Católica do Rio de Janeiro, Rio de Janeiro, 2015.; CALAFATE, Pedro; GUTIÉRREZ, Ramón E. Mandado (dir.). A Escola Ibérica da Paæ: a consciência crítica da conquista e colonização da América/Escuela Ibérica de la Pa:: la consciência critica de la conquista e colonización de América: 1511 - 1694. Santander: Universidade de Cantábria, 2014. Na atualidade, o conceito de recta ratio vem sendo resgatado por Cançado Trindade, atual Juiz da Corte Internacional de Justiça, ao citar os "pais fundadores" do Direito Internacional em seus votos (Cfr., inter alia, os três casos envolvendo as Ilhas Marshall (contra Reino Unido, Índia e Paquistão), o caso Croácia v. Sérvia e o caso Alemanha v. Itália, com intervenção da Grécia. Cfr., ainda, TRINDADE, Antônio Augusto Cançado. A bumanização do direito internacional. Belo Horizonte: Del Rey, 2006. p. 6-29).

28 Em Carta Régia de 13 de maio de 1808, a Coroa Portuguesa declarou guerra justa contra o Povo Krenak, sob a alegação de antropofagia. CÂMARA DOS DEPUTADOS. Carta Régia de 13 de maio de 1808. Disponível em: http://www2.camara.leg.br/ legin/fed/carreg_sn/anterioresa1824/cartaregia-40169-13-maio-1808-572129-publicacaooriginal-95256-pe.html. Acesso em: 23 maio 2019.

29 Em sentido contrário, merecem destaque as denúncias de violações de direitos humanos contra indígenas que foram enviadas ao Tribunal Russell II (1974-1976) e ao Tribunal Russel IV (1980), citados, inclusive, no Relatório da CNV. BRASIL. Comissão Nacional da Verdade. Relatório final. Brasília: CNV, 2014. v. 2, texto 5. p. 208. Disponível em: http://cnv.memoriasreveladas.gov.br/. Acesso em: 10 maio 2019.

30 Outrossim, conforme o Relatório final da CNV, houve também a instalação de diversas Comissões Parlamentares de Inquérito para apurar esses tipos de violações de direitos humanos e a elaboração do Relatório Figueiredo - relatório produzido em 1967 pelo Procurador Jader de Figueiredo Correa que apurou matanças de comunidades inteiras, torturas e toda sorte de crueldades praticadas contra indígenas em todo o país desde a década de 40. O Referido relatório, supostamente eliminado em um incêndio no Ministério da Agricultura, foi encontrado no Museu do Índio (RJ), contendo 29 dos 30 tomos originais. BRASIL. Comissão Nacional da Verdade. Relatório final. Brasília: CNV, 2014. v. 2, texto 5. p. 208. Disponível em: http://cnv.memoriasreveladas.gov.br/. Acesso em: 10 maio 2019.

31 Por fim, cite-se o Grupo de Trabalho sobre violações de direitos humanos relacionadas à luta pela terra e contra populações indígenas, por motivações políticas, instituído pela Resolução no 5/2012, no âmbito da CNV.

32 Nesse ponto, saliente-se que, com a edição do Decreto nº 66.882, em 1970, a FUNAI incorporou formalmente atividades de assessoramento de segurança e informações à sua estrutura, por meio de uma "Seção de Segurança e Informações", vinculada à Divisão de Segurança e Informações (DSI) do Ministério do Interior, o que fortaleceu o ideal da doutrina da segurança nacional de que as terras indígenas e seus modos de vida seriam obstáculos ao desenvolvimento e à segurança da Nação. 
povos indígenas durante o período.

O primeiro rol de violações será dedicado a analisar o massacre do povo indígena Waimiri-Atroari (Kinja ou Kiña), ocorrido na fronteira entre os estados do Amazonas e de Roraima em razão da suposta necessidade de se levar progresso e desenvolvimento à região Norte. Já o segundo rol analisará a instalação do Reformatório Krenak e da Guarda Rural Indígena (GRI) no território do povo indígena Krenak, além de determinações de deslocamentos forçados desse povo pelo SPI e pela FUNAI, fatos que tiveram lugar em Minas Gerais.

\subsection{As violações praticadas contra o povo indígena Waimiri-Atroari}

Segundo o Relatório da CNV, os Waimiri-Atroari foram massacrados, entre os anos 1960 e 1980, como parte de um plano oficial do Estado para removê-los de seu território e atraí-los com o objetivo exclusivo de acelerar seu processo de integração na sociedade nacional. Em 1972, segundo dados da FUNAI, os Waimiri-Atroari possuíam uma população de cerca de 3 mil pessoas, as quais foram reduzidas para 420, em 1987, e apenas 350 pessoas, em 1983.

Isso porque ao Estado brasileiro, naquele momento, interessava tão somente providenciar a abertura da BR-174 (Manaus-Boa Vista), a construção da hidroelétrica de Balbina e, ainda, assegurar a atuação de mineradoras e garimpeiros interessados em explorar jazidas que existiam naquele território.

Extrai-se do Relatório da CNV uma verdadeira política estatal genocida e etnocida institucionalizada para exterminar a cultura e o modo de vida dos Waimiri-Atroari, inclusive porque o contato com esse povo indígena "já havia sido tentado desde o início do século, mas não havia tido sucesso em razão da abundância de malocas indígenas em diferentes rios e da resistência dos índios à invasão de seu território" 33 . Nesse panorama, para alcançar os objetivos fixados pelo governo militar, relacionados à construção da BR-174, segundo o Relatório:

[...] a partir de 1968, foi criado entre a Funai, o Departamento Nacional de Estradas de Rodagem (DNER), o Instituto de Terras (ITERAM), o Ministério da Aeronáutica e o Grupamento Especial de Fronteiras do Exército um plano de ação para possibilitar a invasão do território Waimiri-Atroari e a execução dos projetos econômicos do governo militar para aquela região. A criação dos Postos Indígenas de Atração (PIA) nos rios Camanaú, em 1969, Alalaú, em 1970, e Santo Antônio do Abanari, em 1972, ocorreu como consequência desse plano e visava a remoção dos índios e de suas malocas do traçado da rodovia. Em relatório da Frente de Atração Waimiri-Atroari lê-se que o PIA: tem como principal objetivo realizar a atração dos grupos indígenas Waimiri-Atroari acelerando seu processo de integração na sociedade nacional, assim como realizar trabalhos de apoio aos serviços da estrada BR$174^{34}$.

A construção da BR-174 - a revelia da vontade dos índios e permeadas de atos violentos por parte do Estado brasileiro que funcionava sob a "lógica militar de guerra" — foi finalizada em 1979. Durante 1968 e 1979, são diversos os relatos que apontam para o genocídio desse povo indígena, seja por intermédio de bombardeios terrestres, seja por meio de bombardeios aéreos, inclusive com a utilização de napalm (composta por sais de alumínio e por ácidos naftétnico e palmítico, ao ser misturada com gasolina, torna-se uma substância explosiva), para garantir que a estrada não tivesse seu curso alterado e passasse por dentro do território Waimiri-Atroari.

Já no ano de 1981, na mesma região, é iniciada a construção da usina hidroelétrica de Balbina “e, para tanto, o general Figueiredo desmembrou a parte leste da terra indígena Waimiri-Atroari por meio do Decre-

\footnotetext{
33 BRASIL. Comissão Nacional da Verdade. Relatório final. Brasília: CNV, 2014. v. 2, texto 5. p. 234. Disponível em: http://cnv. memoriasreveladas.gov.br/. Acesso em: 10 maio 2019.

34 BRASIL. Comissão Nacional da Verdade. Relatório final. Brasília: CNV, 2014. v. 2, texto 5. p. 234. Disponível em: http://cnv. memoriasreveladas.gov.br/. Acesso em: 10 maio 2019.
} 
to n'. 86.630" ".35 Aproximadamente 30.000 mil hectares foram inundados, o que ocasionou a remoção de, pelo menos, duas aldeias.

O desmembramento autorizado pelo já citado Decreto no 86.603/1981 também serviu aos interesses das mineradoras Timbó/Parapanema e Taboca que, desde a década de 70, pediam autorização para prospecção mineral na área. Com o decreto de Figueiredo, as mineradoras Timbó/Parapanema e Taboca puderam se estabelecer numa área de 526.800 hectares dentro da reserva Waimiri-Atroari.

As empresas em questão, além de celebrarem um contrato com a FUNAI em 1982 para permitir a construção de outra estrada dentro das terras Waimiri-Atroari com a extensão de 38 quilômetros, possuíam autorização do Comando Militar da Amazônia para "manter ao seu serviço 400 homens equipados com cartucheiras 20 milímetros, rifle 38, revólveres de variado calibre e cães amestrados" ${ }^{\text {"36 }}$, tendo sido contratada uma empresa paramilitar chamada Sacopã, especializada em "limpar a selva".

Por fim, as terras dos Waimiri-Atroari foram invadidas por posseiros e fazendeiros que se instalavam às margens da BR-174 e ao sul da reserva, sendo certo também que

[...]o governo militar apoiou ainda iniciativas de colonização do território Waimiri-Atroari, com financiamentos de atividades agropecuárias por meio dos programas Polo Amazônia e Proálcool, que beneficiaram, entre outras empresas, a Agropecuária Jayoro. ${ }^{37}$

A miríade de violações ocorridas em curto lapso temporal é tão extensa que é quase inacreditável que, até hoje, não tenha havido qualquer espécie de reparação ao povo indígena Waimiri-Atroari.

\subsection{As violações praticadas contra o povo indígena Krenak}

Igualmente avassaladoras são as graves violações de direitos humanos praticadas pelo regime de exceção brasileiro em relação ao povo indígena Krenak. Ao final dos anos 60, depois do AI-5, o Estado brasileiro criou uma cadeia oficial dentro do território Krenak, especificamente no município de Resplendor/MG, exclusiva para a detenção de indígenas considerados criminosos ou com comportamentos tidos como desviantes, sendo certo que a CNV colheu "denúncias de casos de morte por tortura no tronco, trabalho forçado e desaparecimento de prisioneiros". 38

Sobre o assunto, a CNV transcreveu, inclusive, parte da denúncia contida em documento enviado ao Tribunal Russell II, em 1974:

[...] com relação aos índios, o clima é de terror. Contrariando seus Estatutos e atentando contra os direitos humanos, a Funai criou uma prisão para os índios em Crenaque, no município de Governador Valadares, Minas Gerais. Na gestão de Bandeira de Melo [Presidente da FUNA] a prisão tem sido muito usada. Segundo palavras do sertanista Antonio Cotrim Soares, jamais contestadas pela Funai, Crenaque "é um campo de concentração" para onde são enviados os índios revoltados com o sistema explorador e opressivo da Funai. A prisão é dirigida por um oficial da PM de Minas Gerais [capitão Manoel Pinheiro], comandando um destacamento de seis soldados. Os índios presos são obrigados a um regime de trabalho forçado de oito horas diárias. São colocados em prisões celulares, isolados uns dos outros. E recebem espancamentos e torturas. Cotrim conta o caso do índio Oscar Guarani, de Mato Grosso, que ao entrar na prisão pesava 90 quilos e de lá saiu pesando 60, além de apresentar marcas de sevícias no corpo [em tempo, segundo a própria CNV, o crime de Oscar Guarani foi ter ido

\footnotetext{
35 BRASIL. Comissão Nacional da Verdade. Relatório final. Brasília: CNV, 2014. v. 2, texto 5. p. 235. Disponível em: http://cnv. memoriasreveladas.gov.br/. Acesso em: 10 maio 2019.

36 BRASIL. Comissão Nacional da Verdade. Relatório final. Brasília: CNV, 2014. v. 2, texto 5. p. 236. Disponível em: http://cnv. memoriasreveladas.gov.br/. Acesso em: 10 maio 2019.

37 BRASIL. Comissão Nacional da Verdade. Relatório final. Brasília: CNV, 2014. v. 2, texto 5. p. 236. Disponível em: http://cnv. memoriasreveladas.gov.br/. Acesso em: 10 maio 2019.

38 BRASIL. Comissão Nacional da Verdade. Relatório final. Brasília: CNV, 2014. v. 2, texto 5. p. 239-240. Disponível em: http:// cnv.memoriasreveladas.gov.br/. Acesso em: 10 maio 2019.
} 
a Brasília apresentar reivindicações à direção da Funai, sendo preso após se desentender, nos corredores da instituição, com um militar que não permitiu seu encontro com o presidente da instituição. Ficou detido por três anos $]^{39}$.

Contabiliza-se que, pelo menos, 121 índios, de várias etnias ${ }^{40}$, foram encarcerados no conhecido Reformatório Krenak entre os anos de 1969 e 1979, muitos deles sem qualquer ordem judicial.

A CNV, ao visitar as ruínas da prisão clandestina na terra indígena Krenak, colheu o depoimento do ancião Oredes Krenak, o qual contou que eles [indígenas] eram punidos por coisas pequenas, como desobediência por não aceitar fazer trabalho forçado, ou quando não faziam o que lhes era pedido por não saber fazer. E qual seria essa punição? O próprio Oredes Krenak relembra: "a punição era: ficar presos, passar dois dias sem comer, mais dois dias só com duas refeições, e só eram soltos no quinto dia. Na cadeia, muitos passavam fome, ficavam sem comer nem beber" ${ }^{\prime 41}$.

Muitas perguntas sobre o que aconteceu naquela cadeia oficial, símbolo da violência e arbitrariedade com as quais foram tratados os povos indígenas durante o regime de exceção, permanecem sem respostas, como asseverou a CNV:

quais serão as memórias dos 121 presos indígenas listados? Quantos indígenas foram presos sem registros? De quais etnias seriam esses presos sem documentação? Quais foram torturados e quantos desapareceram? Quem são os responsáveis pelas violências, torturas e desaparecimentos de índios na cadeia do Krenak? Qual a estrutura de comando acima do capitão Pinheiro?

A CNV, mesmo que ainda não tenha as respostas para as questões acima, com base na documentação reunida reconhece, no Reformatório Krenak e na Fazenda Guarani (que o sucedeu), a sua abrangência nacional quanto à função de prisão de índios rebeldes, encarcerando indígenas de 23 etnias. Ademais, especificamente para a população Krenak, obrigada a viver sob as mesmas condições de índios presos em suas terras, o reformatório assume um caráter de "campo de concentração", conforme denunciado no Tribunal Russell II, ou "prisão domiciliar", como descrito no caso Aikewara. Os indícios levantados relacionam esse reformatório aos centros de torturas e, portanto, as investigações deverão ser aprofundadas pelo Estado brasileiro ${ }^{42}$.

Afora as diversas violações relacionadas ao Reformatório Krenak, o povo indígena Krenak sofreu também as consequências da instituição da Guarda Rural Indígena (GRI) no ano de 1969 e, ainda, com determinações de deslocamentos forçados pelo SPI e pela FUNAI.

Quanto à Guarda Rural Indígena, entidade criada para recrutar índios para atuar como força policial nas áreas indígenas, a CNV conseguiu apurar tão somente que houve denúncias de "arbitrariedades, espancamentos, e abusos de toda a sorte" ${ }^{43}$, considerando imprescindível que as investigações fossem aprofundadas, o que, até o momento, não ocorreu.

Ainda que os relatos apontem para um curto período de atuação da Guarda Rural Indígena, a própria criação de uma espécie de polícia indígena destinada a "fiscalizar" os próprios indígenas, inclusive, com as vestimentas e técnicas policiais típicas de um período de exceção, desestruturando a hierarquia tradicional-

\footnotetext{
39 BRASIL. Comissão Nacional da Verdade. Relatório final. Brasília: CNV, 2014. v. 2, texto 5. p. 244. Disponível em: http://cnv. memoriasreveladas.gov.br/. Acesso em: 10 maio 2019.

40 Extrai-se do Relatório da CNV: "Foram identificados pelo nome: 22 Karajá, 17 Terena, 13 Maxacali, 11 Pataxó, nove Krenak, oito Kadiweu, oito Xerente, seis Kaiowá, quatro Bororo, três Krahô, três Guarani, dois Pankararu, dois Guajajara, dois Canela, dois Fulniô e um Kaingang, Urubu, Campa, Xavante, Xakriabá, Tupinikim, Sateré-Mawé, Javaé, além de um não identificado, porém, o número de índios presos na ditadura militar pode ser maior". Cfr.: BRASIL. Comissão Nacional da Verdade. Relatório final. Brasília: CNV, 2014. v. 2, texto 5. p. 239-240 e 244. Disponível em: http://cnv.memoriasreveladas.gov.br/. Acesso em: 10 maio 2019 ,

41 BRASIL. Comissão Nacional da Verdade. Relatório final. Brasília: CNV, 2014. v. 2, texto 5. p. 245. Disponível em: http://cnv. memoriasreveladas.gov.br/. Acesso em: 10 maio 2019.

42 BRASIL. Comissão Nacional da Verdade. Relatório final. Brasília: CNV, 2014. v. 2, texto 5. p. 245. Disponível em: http://cnv. memoriasreveladas.gov.br/. Acesso em: 10 maio 2019.

43 BRASIL. Comissão Nacional da Verdade. Relatório final. Brasília: CNV, 2014. v. 2, texto 5. p. 212. Disponível em: http://cnv. memoriasreveladas.gov.br/. Acesso em: 10 maio 2019.
} 
mente existente nas comunidades, já possibilita mensurar a enormidade da violação à cultura desse povo. $\mathrm{Na}$ formatura da $1^{a}$ turma da GRI, foram feitas imagens históricas de soldados da própria Guarda carregando um homem pendurado em um pau de arara $^{44}$.

Antes mesmo da instalação do Reformatório e da criação da GRI, o povo indígena Krenak havia sido deslocado forçosamente "de seu território, no município de Resplendor (MG) para a região de Águas Formosas em 1957". A decisão, tomada com o aval do SPI (antecessor da FUNAI), "respondia à última etapa da ação do órgão para liberar as terras para colonização, foi tomada de forma atropelada e sem nenhum início do planejamento da direção acerca da transferência dos Krenak". Como atestou a CNV,

[...] frente às péssimas condições de vida no posto de Águas Formosas, os indígenas retornam a pé, de carro e de trem em uma viagem de três meses e cinco dias ${ }^{45}$.

Em dezembro de 1972, novo deslocamento forçado foi coordenado em razão da demonstração de interesses econômicos na terra tradicionalmente ocupada pelos Krenak. Dessa vez para levar os indígenas para a Fazenda Guarani, situada no município de Carmésia/MG, local que também serviu como prisão indígena. Somente na década de 80, o povo indígena Krenak, mesmo receoso com eventual violência por parte dos agentes do Estado e dos fazendeiros, começou a retornar ao seu território.

Esse conjunto de graves violações de direitos humanos causou grande desagregação social e cultural do povo indígena Krenak, podendo ser rotulada, inclusive, como verdadeira política etnocida do Estado brasileiro.

\section{As aproximações existentes entre o constitucionalismo pluralista latino-americano e a Constituição Federal de 1988}

Para Raquel Yrigoyen Fajardo, o constitucionalismo pluralista, iniciado na década de 80 e em andamento até os dias atuais no âmbito do movimento do Novo Constitucionalismo Latino-Americano, apresenta três ciclos de reformas constitucionais e aponta para a construção e consolidação de um Estado que reconhece o direito à diversidade e à identidade cultural dos povos indígenas ${ }^{46}$.

Busca-se, portanto, o pluralismo jurídico, o qual pode ser definido como a convivência ou coexistência de mais de um sistema normativo no mesmo espaço geopolítico. Em suma, o horizonte constitucionalista proposto reconhece que "os povos indígenas possuem dignidade e direitos, não estando sujeitos à tutela colonial" 47 e desconstitui a ideologia de inferioridade "natural".

Esse processo de reconstrução do paradigma constitucional, retirando os povos originários da posição subordinada que lhes foi imposta, é iniciado com a emergência do multiculturalismo sem alcançar o pluralismo jurídico (primeiro ciclo - 1982-1988), passa pelo reconhecimento do modelo de Estado pluricultural e o

\footnotetext{
44 Cfr. reportagem da Folha de São Paulo intitulada "Como a ditadura ensinou técnicas de tortura à Guarda Rural Indígena". CAPRIGLIONE, Laura. Como a ditadura ensinou técnicas de tortura à Guarda Rural Undígena. Folha de S. Paulo, São Paulo, 11 nov. 2012. Disponível em: https://www1.folha.uol.com.br/ilustrissima/2012/11/1182605-como-a-ditadura-ensinou-tecnicas-de-tortura-a-guarda-rural-indigena.shtml. Acesso 25 abr. 2019.

45 BRASIL. Comissão Nacional da Verdade. Relatório final. Brasília: CNV, 2014. v. 2, texto 5. p. 210. Disponível em: http://cnv. memoriasreveladas.gov.br/. Acesso em: 10 maio 2019.

46 Cfr.: FAJARDO, Raquel Yrigoyen. El horizonte del constitucionalismo pluralista: del multiculturalismo a la descolonización. In: GARAVITO, César Rodríguéz (coord.). El derecho en la America Latina: un mapa para el pensamiento jurídico del siglo XXI. Buenos Aires: Siglo Veintiuno Editores, 2011. p. 140-143 e 149-154.

47 FAJARDO, Raquel Yrigoyen. Pluralismo jurídico y jurisdicción indígena en el horizonte del constitucionalismo pluralista In: AHRENS, Helen (comp.). El estado de derecho hoy en América Latina: livro em homenagem a Horst Schönbohm. México: UNAM, Instituto de Investigações Jurídicas, 2016. (Coleção Fundação Konrad Adenauer). p. 171. Disponível em: https://www. kas.de/documents/252038/253252/7_dokument_dok_pdf_31788_4.pdf/2a209f4a-6317-211c-9b00-1b66721b18b3?version=1.0 $\& \mathrm{t}=1539656876906$. Acesso em: 2 jan. 2019. As citações diretas dessa obra são traduções livres do texto original em espanhol.
} 
pluralismo jurídico (segundo ciclo - 1989-2005) até, por fim, restar caracterizado que os povos indígenas se constituem em nações ou nacionalidades originárias e, fazendo um novo pacto com o Estado, conformam um Estado plurinacional (terceiro ciclo - 2006-2009).

No primeiro ciclo (multicultural), as Constituições introduzem os conceitos de diversidade cultural e de identidade cultural, além de reconhecer a configuração multicultural e multilíngue da sociedade. Exemplos desse marco são as Constituições do Canadá (1982), da Guatemala (1985) e Nicarágua (1987). A Constituição brasileira de 1988, como se verá detalhadamente abaixo, também é incluída nesse ciclo, mas já apresenta parte das características do ciclo seguinte.

Por seu turno, o segundo ciclo (pluricultural) caracteriza-se por apresentar Constituições que reconhecem constitucionalmente os direitos — seja de forma individual, seja de forma coletiva — de identidade e diversidade cultural, desenvolvendo, ainda, os conceitos de nação multiétnica e Estado pluricultural. Nesse marco, encontra-se a adoção da Convenção 169 da OIT, em 1989, e as Constituições de diversos países latino-americanos ${ }^{48}$. O grande destaque desse ciclo, todavia, refere-se à introdução do pluralismo jurídico que rompe com a identidade Estado-direito monista.

Já o terceiro ciclo (plurinacional), explicitado pela adoção da Declaração das Nações Unidas sobre os Direitos dos Povos Indígenas (2007) e pelas Constituições de Bolívia (2006-2009) e Equador (2008), aponta, explicitamente, para um projeto "descolonizador", afirmando peremptoriamente o Princípio do Pluralismo Jurídico, a igual dignidade dos povos e culturas e a interculturalidade, conceitos que são traduzidos, em análise última, no direito à autodeterminação ou livre determinação dos povos. Assim, a constitucionalização do pluralismo jurídico põe fim à monoculturalidade estatal ${ }^{49}$.

Sedimenta-se, assim, a ideia de Estado plurinacional e se reconhece, constitucionalmente, o direito à diversidade cultural e à identidade, o que, por sua vez, ocasiona a revisão dos conceitos de legitimidade e participação popular, especialmente de parcela da população historicamente excluída dos processos de decisão, como a população indígena. Sobre o assunto, Raquel Yrigoyen Fajardo sintetiza:

[...] as reformas constitucionais mais importantes ocorridas nas últimas três décadas impactaram a própria definição do modelo de Estado e reconfiguraram a relação jurídica entre os Estados e os povos indígenas. Estas reformas foram feitas segundo o horizonte da Convenção 169 da OIT; com exceção do Chile, todos os países andinos mudaram a Constituição (Colômbia em 1991, Peru em 1993, Bolívia em 1994-2007, Equador em 1998 e 2008, e Venezuela em 1999) incorporando elementos da Convenção 169. Entre tais reformas, cabe ressaltar as que seguem: (a) o reconhecimento do caráter pluricultural do Estado/nação/república, e o direito à identidade cultural, individual e coletiva, o que permite superar a ideia de Estado-nação monocultural e monolíngue; (b) o reconhecimento da igual dignidade das culturas, que rompe com a supremacia institucional da cultura ocidental sobre as demais; (c) o caráter do sujeito político dos povos e comunidades indígenas e campesinas. Os povos indígenas têm direito ao controle das suas instituições políticas, culturais e sociais e seu desenvolvimento econômico, o que permite superar o tratamento tutelar desses povos, como objeto de políticas que ditam terceiros; (d) o reconhecimento de diversas formas de participação, consulta e representação direta de povos indígenas, campesinos e afrodescendentes, o que supera a ideia de que apenas os funcionários públicos representam e podem formar a vontade popular; (e) o reconhecimento do direito (consuetudinário) indígena e a jurisdição especial. Isto supõe uma forma de pluralismo jurídico interno. Todos os países andinos incorporaram na Constituição alguma fórmula de pluralismo legal reconhecendo autoridades indígenas ou campesinas, funções de justiça ou jurisdicionais, e o direito indígena ou suas próprias normas e procedimentos; (f) junto a isso, o reconhecimento de um conjunto de direitos relativos à terra,

\footnotetext{
48 Entre eles: Colômbia (1991), México (1992), Paraguai (1992), Peru (1993), Bolívia (1994), Equador (1996 e 1998$)$ e Venezuela (1999).

49 Cfr., nesse sentido: FAJARDO, Raquel Yrigoyen. Pluralismo jurídico y jurisdicción indígena en el horizonte del constitucionalismo pluralista In: AHRENS, Helen (comp.). El estado de derecho hoy en América Latina: livro em homenagem a Horst Schönbohm. México: UNAM, Instituto de Investigações Jurídicas, 2016. (Coleção Fundação Konrad Adenauer). p. 171. Disponível em: https:// www.kas.de/documents/252038/253252/7_dokument_dok_pdf_31788_4.pdf/2a209f4a-6317-211c-9b00-1b66721b18b3?version $=1.0 \& \mathrm{t}=1539656876906$.
} 
as formas organizacionais coletivas, educação bilíngue intercultural, oficialização de idiomas indígenas etc. [...] (Tradução livre) $)^{50}$.

No mesmo contexto em que inserido o constitucionalismo pluralista, a Constituição de 1988 inaugura a mudança na proteção dos direitos indígenas no Brasil ao romper o paradigma até então vigente de que a condição de indígena era transitória e deveria ser respeitada até a sua integração "progressiva e harmoniosamente à comunhão nacional'51.

Assim, o Estado brasileiro, pelo menos no texto constitucional e de forma pioneira, "embora sem coragem para declarar o país multiétnico e pluricultural" 52 , para utilizar as palavras de Frederico Marés, garantiu o direito de ser e continuar sendo índio, reconhecendo-lhes seus costumes e tradições (art. 231). Em outras palavras, a Constituição atual assegura juridicamente aos povos indígenas o "resgate" de sua cultura e modo de viver.

Nesses termos, a partir de 1988, o marco constitucional brasileiro encontra-se inserido no que Raquel Yrigoyen Fajardo intitula primeiro ciclo do constitucionalismo pluralista, já na fase de transição para o segundo ciclo:

[...] o primeiro ciclo de reformas constitucionais que cabe ser colocado no horizonte do constitucionalismo pluralista desenvolveu-se durante os anos oitenta do século XX (1982-1988) e está marcado pelo surgimento de multiculturalismo e por novas demandas indígenas. Neste ciclo, as Constituições introduzem o conceito de diversidade cultural, o reconhecimento da configuração multicultural e multilíngue da sociedade, o direito — individual e coletivo - à identidade cultural e alguns direitos indígenas específicos.

A Constituição do Canadá (1982) abre a lacuna então existente com um reconhecimento pioneiro de sua herança multicultural (multicultural heritage) e com a incorporação de direitos aborígenes (rights of aboriginal peoples). Duas constituições da América Central, a da Guatemala em 1985 e da Nicarágua em 1987, também fazem parte deste horizonte, procurando reconciliar suas sociedades e dar respostas às demandas indígenas no contexto de conflitos.

A Constituição da Guatemala reconhece a configuração multiétnica, multicultural e multilíngue do país e "o direito dos indivíduos e comunidades à sua identidade cultural", bem como certos direitos específicos para grupos étnicos e comunidades indígenas. A Constituição da Nicarágua também reconhece a "natureza multiétnica" do povo, assim como os direitos culturais, linguísticos e territoriais das comunidades étnicas do Attântico, para que possam se organizar de acordo com "suas tradições históricas e culturais" e desenvolver um sistema de autonomias. A Constituição Brasileira de 1988, que antecede e um ano a adoção da Convenção 169 da OIT sobre os direitos indígenas, e reconhece algumas questões debatidas por ocasião da revisão da Convenção 107 da OIT, está localizada no limiar para o segundo ciclo (tradução livre) ${ }^{53}$.

Ao tratar sobre os direitos territoriais indígenas à luz do texto constitucional atual e a partir de uma interpretação intercultural, Julio José Araujo Junior assevera que a "Constituição Federal de 1988 não fechou os olhos à ferida colonial”, sendo certo que é possível extrair de seu texto

[...]um potencial transformador, que repudia o racismo e incita a construção livre, justa e solidária, comprometida com erradicação da pobreza e o enfrentamento das desigualdades.

\footnotetext{
50 FAJARDO, Raquel Yrigoyen. Hitos del reconocimiento del pluralismo jurídico y el derecho indigena en las políticas indigenistas y el constitucionalismo andino. In: BERRAONDO, Mikel (coord.). Pueblos indigenas y derechos humanos. Bilbao: Universidad de Deusto, 2006. p. 30-31. Disponível em: http://www.alertanet.org/ryf-hitos-2006.pdf. Acesso em: 20 fev. 2019.

51 Nesse sentido, é expresso o Estatuto do Índio (Lei no . 6.001/73 - Art. 1 ${ }^{\circ}$.): "Esta Lei regula a situação jurídica dos índios ou silvícolas e das comunidades indígenas, com o propósito de preservar a sua cultura e integrá-los, progressiva e harmoniosamente, à comunhão nacional".

52 SOUZA FILHO, Carlos Frederico Marés. O renascer dos povos indígenas para o direito. Curitiba: Juruá, 2012. p. 185.

53 FAJARDO, Raquel Yrigoyen. El horizonte del constitucionalismo pluralista: del multiculturalismo a la descolonización In: GARAVITO, César Rodriguéz (coord.). El derecho en la America Latina: un mapa para el pensamiento jurídico del siglo XXI. Buenos Aires: Siglo Veintiuno Editores, 2011. p. 141.
} 
Mais que isso: a Carta Constitucional enfatiza "a autonomia dos povos indígenas, com respeito a seus modos de vida, costumes, tradições e mediante o reconhecimento das terras que tradicionalmente ocupa" e, por isso, "a compreensão sobre os conceitos exarados na Constituição deve ser aberta à incidência de múltiplas cosmovisões, sem estabelecer a precedência dos valores hegemônicos" ${ }^{54}$.

Com essas premissas, e para que haja sucesso na interpretação intercultural, é indispensável que ocorra a "ampliação de canais e espaços que assegurem o protagonismo indígena de alta intensidade" ${ }^{55}$. Em síntese, prossegue o autor:

a suplantação de olhares coloniais e até de interpretações como a ora proposta depende de uma ativa manifestação dos indígenas acerca de suas percepções sobre o tema [...]. Novos arranjos de participação e internalização, por meio da interpretação, de cosmovisões indígenas, colhendo-se os bons frutos do constitucionalismo andino, são tarefas prementes.

Indubitavelmente, o mesmo raciocínio deve ser aplicado à justiça de transição brasileira sob pena de, mais uma vez, os povos indígenas serem invisibilizados no processo — ainda em curso — de reconciliação com passado recente.

Isso porque, mesmo diante da gravidade dos fatos, até em razão da invisibilidade já citada, as violações perpetradas contra os povos indígenas Waimiri-Atroari, Krenak e tantos outros no período de exceção fez com que a justiça transicional brasileira não levasse em consideração, na estruturação de seus mecanismos, as especificidades das violações e das reparações necessárias no caso dessas comunidades.

Impõe-se, portanto, mais um desafio ao já desconexo processo transicional brasileiro: a adequação dos mecanismos transicionais que, até o momento, são primordialmente centrados no indivíduo, para possibilitar, no caso dos povos indígenas, a reparação de violações que atingiram a própria existência do ser coletivo (povo).

Para tanto, o desenvolvimento do horizonte pluralista no modelo constitucional brasileiro, seja em razão do já citado art. 231, seja em virtude da internalização da Convenção 169 da OIT, surge como fundamento teórico adequado para viabilizar uma justiça de transição aos povos indígenas.

\section{Considerações finais}

O constitucionalismo pluralista latino-americano - enquanto "grande projeto descolonizador" que expressa resistência aos antigos e novos colonialismos — questiona o próprio fato colonial que é embasado na ideologia de "inferioridade natural dos índios" e coloca os povos originários em uma posição subordinada, forçando-os à conversão a "cidadãos" 56 .

Descortina-se, assim, um novo paradigma constitucional em busca do pluralismo jurídico. A Constituição Federal de 1988 já deu o passo indispensável para que os povos indígenas possuam seu lugar de falar e sua representatividade, bem como tenham sua diversidade e identidade culturais respeitadas.

Nesse contexto, o enfrentamento da violação dos direitos humanos dos povos indígenas no regime de exceção brasileiro é premente e deve ser auxiliado pelo atual viés pluralista adotada pela Carta Constitucional de 1988.

54 ARAUJO JUNIOR, Julio José. Direitos territoriais indígenas: uma interpretação intercultural. Rio de Janeiro: Processo, 2018. p. 305-306.

55 ARAUJO JUNIOR, Julio José. Direitos territoriais indígenas: uma interpretação intercultural. Rio de Janeiro: Processo, 2018 . p. 367.

56 FAJARDO, Raquel Yrigoyen. El horizonte del constitucionalismo pluralista: del multiculturalismo a la descolonización In: GARAVITO, César Rodriguéz (coord.). El derecho en la America Latina: un mapa para el pensamiento jurídico del siglo XXI. Buenos Aires: Siglo Veintiuno Editores, 2011. p. 139. As citações diretas dessa obra são traduções livres do texto original em espanhol. 
O processo de justiça transicional ainda se encontra incompleto, mesmo para as graves violações de direitos humanos perpetradas contra a sociedade envolvente. Quando se analisa a situação dos povos indígenas, a dita incompletude beira à completa ausência de justiça de transição. A investigação iniciada pela CNV, como ela mesma destacou, "precisa de continuidade para que esses povos participem e sejam beneficiados pelo processo de justiça transicional em desenvolvimento no Brasil" ${ }^{57}$.

Recentes iniciativas do Ministério Público Federal no Amazonas (no caso dos Waimiri-Atroari) e em Minas Gerais (no caso dos Krenak) geraram o ajuizamento de ações civis públicas. No primeiro caso, busca-se

[...] apresentar os fatos que culminaram no extermínio de membros do povo Waimiri-Atroari e pedir provimento jurisdicional que assegure a reparação pelos danos causados, cujos efeitos são sentidos até hoje, bem como garantias de que jamais se repitam violações similares, com vistas a assegurar a efetiva paz no território Kinja (ACP 1001605-06.2017.401.3200).

Por sua vez, no segundo caso, pretende-se enfrentar as graves violações de direitos humanos relacionadas ao povo indígena Krenak, mormente em razão da criação da Guarda Rural Indígena, da instalação do Reformatório Krenak e do deslocamento forçado de indígenas, de diversas etnias, principalmente da Krenak, para a Fazenda Guarani, localizada no município de Carmésia/MG, que também funcionou como centro de detenção arbitrária de indígenas após a extinção do Reformatório Krenak (ACP 64483-95.2015.4.01.3800).

Em ambas as ações, o Ministério Público Federal aponta para a necessidade de mecanismos de justiça de transição específicos para os povos indígenas e que respeitem seus modos de vida e costumes.

No caso dos Waimiri-Atroari, o Parquet federal elencou, entre os pedidos formulados na inicial, a necessidade de:

Quadro 1

\begin{tabular}{|l|l|}
\hline $\mathbf{( 1 )}$ & $\begin{array}{l}\text { "preservação de locais sagrados, cemitérios e espaços territoriais imprescindíveis de pertenci- } \\
\text { mento ao povo que sejam impactados pela rodovia, mediante indicação e sinalização, observado } \\
\text { o art. 60 da Convenção no 169/OIT"; }\end{array}$ \\
\hline $\mathbf{( 2 )}$ & $\begin{array}{l}\text { realização de "cerimônia pública de pedido de desculpas na Terra Indígena Waimiri-Atroari, } \\
\text { com a presença de representantes do Poder Executivo Federal e Estadual, com convite às auto- } \\
\text { ridades dos municípios circunvizinhos àquela Terra Indígena, em data e formato a serem acor- } \\
\text { dados antecipadamente com os Kinja, com máxima publicidade dos atos praticados em todos } \\
\text { os meios de comunicação de que dispõe o Estado brasileiro, observado o disposto no art. 60 da } \\
\text { Convenção no 169/OIT"; }\end{array}$ \\
\hline $\mathbf{( 3 )}$ & $\begin{array}{l}\text { "traduzir para a língua Karib, a Constituição da República de 1988, a Convenção no 169/OIT e } \\
\text { o texto temático do relatório final da Comissão Nacional da Verdade sobre as violações de direi- } \\
\text { tos humanos dos povos indígenas, entregando os textos traduzidos ao povo Waimiri-Atroari"; }\end{array}$ \\
\hline $\mathbf{( 4 )}$ & $\begin{array}{l}\text { "entregar à comunidade todos os documentos governamentais, civis ou militares, mantidos } \\
\text { sob qualquer meio impresso, digital ou audiovisual, produzidos no período da ditadura militar, } \\
\text { referentes à etnia e ao empreendimento de construção da BR174"; }\end{array}$ \\
\hline $\mathbf{( 5 )}$ & $\begin{array}{l}\text { "promover, após consulta prévia, livre e informada à comunidade, a implantação, em parceria } \\
\text { com os indígenas e eventualmente com terceiros interessados, de um Centro de Memória, des- } \\
\text { tinado a manter a memória das violações aos direitos dos povos indígenas no país e no Estado } \\
\text { do Amazonas e"; }\end{array}$ \\
\hline
\end{tabular}

57 BRASIL. Comissão Nacional da Verdade. Relatório final. Brasília: CNV, 2014. v. 2, texto 5. p. 206. Disponível em: http://cnv. memoriasreveladas.gov.br/. Acesso em: 10 maio 2019. 
(6) "garantir a inclusão, no conteúdo programático dos estabelecimentos de ensino médio e fundamental, do estudo das violações dos direitos humanos dos povos indígenas durante a ditadura militar, com destaque ao genocídio do povo Waimiri-Atroari, nos termos do art. 26-A da Lei n०9.394/1996".

Quanto aos Krenak, do mesmo modo, o Ministério Público Federal incluiu, nos pedidos da Ação Civil Pública, a necessidade de:

Quadro 2

(1) "realizar cerimônia pública na Terra Indígena Krenak, com a presença de altos representantes do Poder Executivo Federal e Estadual, durante a qual: a) seja feito pedido público de desculpas ao Povo Krenak pelas graves violações de direito perpetradas contra esta etnia durante a ditadura militar; b) seja destacada a obrigação do Estado, perante a Constituição da República de 1988 e tratados internacionais, de proteger e incentivar os modos de vida dos povos indígenas e de valorizar a diversidade cultural no país; devendo c) a data, o formato e a própria possibilidade de transmissão da cerimônia ser acordados antecipadamente com os Krenak; bem como d) a cerimônia ser transmitida, em rede televisiva pública com cobertura nacional";

(2) “traduzir, para a língua Krenak, a Constituição da República de 1988, a Convenção n 169 da Organização Internacional do Trabalho e o texto temático do relatório final da Comissão Nacional da Verdade sobre as violações de direitos humanos dos povos indígenas, entregando os textos traduzidos ao povo Krenak";

(3) restaurar a "sede da Fazenda Guarani, implantando no local, em parceria com os indígenas e eventualmente com terceiros interessados, um Centro de Memória, destinado a manter a memória das violações aos direitos dos povos indígenas no país e no Estado de Minas Gerais, bem como a abrigar atividades culturais a serem realizadas pelos povos indígenas, desde que o resultado da consulta prévia seja favorável a esta medida";

(4) “implementar ações e apoiar iniciativas indígenas voltadas ao registro, transmissão e ensino da língua Krenak, bem como outras destinadas a resgatar e preservar a cultura do povo Krenak nos seus demais aspectos, as quais deverão ser definidas em consulta prévia a ser realizada na Terra Indígena Krenak";

(5) "garantir a inclusão, no conteúdo programático dos estabelecimentos de ensino médio e fundamental, do estudo das violações dos direitos humanos dos povos indígenas durante a ditadura militar, como forma de conferir efetividade ao disposto no art. 26-A da Lei n 9.394/1996";

(6) "produzir material didático e promover a capacitação dos professores dos ensinos médio e fundamental sobre o tema das violações dos direitos humanos dos povos indígenas durante a ditadura militar, como meio de conferir efetividade ao disposto no art. 26-A da Lei n $9.394 / 1996$ " e;

(7) "produzir, em conjunto com os indígenas, material didático sobre a violação de direitos dos povos indígenas durante a ditadura militar, a ser utilizado nas escolas indígenas, em cumprimento ao disposto no art. 79, $₫ 2^{\circ}$, IV, da Lei n 9.394/1996”.

Tais fatos, por óbvio, corroboram que o horizonte do constitucionalismo pluralista pode ser a fresta aberta para que os povos indígenas busquem as devidas reparações para as graves violações de direitos humanos perpetradas no período de exceção e que atingiram a sua própria existência coletiva.

O processo de justiça de transição brasileiro não deve parar até que haja reparação e consolidação de um regime plenamente democrático e fincado no pluralismo ínsito ao texto constitucional, sendo indubitável, em última análise, que 
[...] para desencadear o diálogo intercultural, é necessário dar voz. Escutar. Enxergar. Permitir que se abra o coração. Nada será pleno sem a participação dos indígenas. Construir caminhos em conjunto é saber e garantir que eles podem, devem e irão falar. E que nós vamos ouvir ${ }^{58}$.

\section{Referências}

AMBOS, Kai et al. Anistia, justiça e impunidade: reflexões sobre justiça de transição no Brasil. Belo Horizonte: Fórum, 2010.

ARAUJO JUNIOR, Julio José. Direitos territoriais indígenas: uma interpretação intercultural. Rio de Janeiro: Processo, 2018.

BRASIL. Comissão Nacional da Verdade. Relatório final. Brasília: CNV, 2014. v. 1,2 e 3. Disponível em: http://cnv.memoriasreveladas.gov.br/. Acesso em: 10 de maio de 2019.

BRASIL. Comissão Nacional da Verdade. Relatório final. Brasília: CNV, 2014. v. 2, texto 5. Disponível em: http://cnv.memoriasreveladas.gov.br/. Acesso em: 10 maio 2019.

BRASIL. Comissão Nacional da Verdade. Relatório final. Brasília: CNV, 2014. v. 1, parte 5. Disponível em: http://cnv.memoriasreveladas.gov.br/. Acesso em: 10 maio 2019.

BRASIL. Exceções Preliminares, mérito, reparações e custas. Sentença de 15 de março de 2018. Série C, n. 353, parágrafo 279.

BRASIL. Exceções preliminares, mérito, reparacõoes e custas. Sentença de 24 de novembro de 2010. Série C, n. 219.

BRASIL. Exceções preliminares, mérito, reparações e custas. Sentença de 15 de março de 2018. Série C, n. 353.

CALAFATE, Pedro; GUTIÉRREZ, Ramón E. Mandado (dir.). A Escola Ibérica da Pą: a consciência crítica da conquista e colonização da América/ Escuela Ibérica de la Paz: la consciência critica de la conquista e colonización de América: 1511 - 1694. Santander: Universidade de Cantábria, 2014.

CÂMARA DOS DEPUTADOS. Carta Régia de 13 de maio de 1808. Disponível em: http:/ /www2.camara. leg.br/legin/fed/carreg_sn/anterioresa1824/cartaregia-40169-13-maio-1808-572129-publicacaooriginal-95256-pe.html. Acesso em: 23 maio 2019.

CAPRIGLIONE, Laura. Como a ditadura ensinou técnicas de tortura à Guarda Rural Undígena. Folha de S. Paulo, São Paulo, 11 nov. 2012. Disponível em: https://www1.folha.uol.com.br/ilustrissima/2012/11/ 1182605-como-a-ditadura-ensinou-tecnicas-de-tortura-a-guarda-rural-indigena.shtml. Acesso 25 abr. 2019.

DALMAU, Rubén Martínez. Asambleas constituíntes e novo constitucionalismo en América Latina. Tempo Exterior, n. 17, p. 5-15, 2008, ISSN 1579-6582, Disponível em: https://dialnet.unirioja.es/servlet/articulo?codigo $=5862528$. Acesso em: 20 mar. 2019.

FAJARDO, Raquel Yrigoyen. Pluralismo jurídico y jurisdicción indígena en el horizonte del constitucionalismo pluralista In: AHRENS, Helen (comp.). El estado de derecho hoy em América Latina: livro em homenagem a Horst Schönbohm. Coleção Fundação Konrad Adenauer. México: UNAM, Instituto de Investigações Jurídicas, 2016. Disponível em: https://www.kas.de/documents/252038/253252/7_dokument_dok_ pdf_31788_4.pdf/2a209f4a-6317-211c-9b00-1b66721b18b3?version=1.0\&t=1539656876906. Acesso em: 2 jan. 2019.

FAJARDO, Raquel Yrigoyen. Aos 20 anos da Convenção 169 da OIT: balanço e desafios da implementação dos direitos dos Povos Indígenas na América Latina In: VERDUM, Ricardo (org.). Povos indígenas: constitui-

58 ARAUJO JUNIOR, Julio José. Direitos territoriais indigenas: uma interpretação intercultural. Rio de Janeiro: Processo, 2018. p. 368. 
ções e reformas políticas na América Latina. Brasília: Instituto de Estudos Socioeconômicos, 2009.

FAJARDO, Raquel Yrigoyen. El horizonte del constitucionalismo pluralista: del multiculturalismo a la descolonización. In: GARAVITO, César Rodríguéz (coord.). El derecho en la America Latina: un mapa para el pensamiento jurídico del siglo XXI. Buenos Aires: Siglo Veintiuno Editores, 2011.

FAJARDO, Raquel Yrigoyen. Hitos del reconocimiento del pluralismo jurídico y el derecho indigena en las políticas indigenistas y el constitucionalismo andino. In: BERRAONDO, Mikel (coord.). Pueblos indígenas y derechos humanos. Bilbao: Universidad de Deusto, 2006. Disponível em: http://www.alertanet.org/ryf-hitos-2006.pdf. Acesso em: 20 fev. 2019.

FREEMAN, Mark. Necessary evils: amenesties and the search for justice. Nova Iorque: Cambridge Press University, 2009.

GARFUNKEL, Ianiv. Verdad y justicia: terminos incompatibles en la justicia transicional. American University International Law Review, v. 32, Iss. 2, Article 7, 2015. Disponível em: https://digitalcommons.wcl.american.edu/auilr/vol32/iss2/7/. Acesso em: 28 mar. 2019.

HÖFFNER, Joseph. La ética colonial española del siglo de oro, cristianismo y dignidad humana. Rivadeneyra: Madrid, 1957.

LOUREIRO, Sílvia Maria da Silveira. A reconstrução da subjetividade coletiva dos povos indígenas no direito internacional dos direitos humanos: o resgate do pensamento da escola ibérica da paz (séculos XVI e XVII) em prol de um novo jus gentium para o século XXI. 2015. Tese (Doutorado) - Pontifícia Universidade Católica do Rio de Janeiro, Rio de Janeiro, 2015.

MEZZAROBA, Orides; MONTEIRO, Cláudia Servilha. Manual de metodologia da pesquisa no direito. 7. ed. São Paulo: Saraiva, 2017.

SANTOS FILHO, Roberto Lemos dos. Direitos humanos dos povos indígenas. In: FERRAZ, Carolina Valença; LEITE, Glauber Salomão. (coord.). Direito à diversidade. São Paulo: Atlas, 2015.

SOUZA FILHO, Carlos Frederico Marés. O renascer dos povos indigenas para o direito. Curitiba: Juruá, 2012.

TRINDADE, Antônio Augusto Cançado. A bumanização do direito internacional. Belo Horizonte: Del Rey, 2006. 
Para publicar na revista Brasileira de Políticas Públicas, acesse o endereço eletrônico www.rbpp.uniceub.br

Observe as normas de publicação, para facilitar e agilizar o trabalho de edição. 